\title{
Effect of Whole Cassava Meal on Performance and Egg Quality Characteristics of Layers
}

\author{
F. A.Aderemi (Corresponding author) \\ Department of Animal Science and Fisheries Management Bowen University Iwo, Osun State Nigeria \\ Tel: 234-803-377-4584Ｅ-mail: faaderemi@yahoo.co.uk
}

T.K. Adenowo

Department of Anatomy and physiology, College of Health Sciences, Bowen University Iwo Nigeria

Tel: 234-803-353-9613Ｅ-mail: tkoa2002@yahoo.com

\section{A.O. Oguntunji}

Department of Animal Science and Fisheries Management Bowen University Iwo, Osun State Nigeria

Tel: 234-813-943-9458Ｅ-mail: abelmendel@yahoo.co.in

Received: June 23, $2011 \quad$ Accepted: July 12, $2011 \quad$ Online Published: December 21, 2011
doi:10.5539/jas.v4n2p195

\begin{abstract}
This study investigated the inclusion of whole cassava meal (WCM) as a replacement to maize at graded levels on the performance and egg quality characteristics of layers fed. The cassava root, leaves and tender stems were harvested chopped separately and dried, ground and mixed at ratio 3:6:1 to get WCM. Five diets were formulated, diets I contained $50 \%$ maize $0 \% \mathrm{WCM}$ and served as the control, diets II $-\mathrm{V}$ had WCM at graded levels of $25,50,75$ and $100 \%$ as a replacement to maize. 40 weeks old laying chickens were used for this feeding trial which lasted for twelve weeks.

Results revealed that beyond $25 \%$ inclusion level feed intake, feed efficiency and the hen day production significantly decreased. From the feed: gain ratio efficiency of utilization declined as the inclusion of WCM increased hence performance characteristics and egg laying ability of the layers were adversely affected. The shell thickness and albumen were however not significantly affected $(\mathrm{P}>0.05)$ by the dietary treatment while yolk colour and haugh unit had no particular statistical trend.

Conclusively $25 \%$ of the maize content of the layers diet could be replaced with whole cassava meal without adverse effect on the performance characteristics and egg quality parameters rather it brought down the cost of production which is desirable.
\end{abstract}

Keywords: Whole cassava meal, Performance and egg quality parameters of layers

\section{Introduction}

The importance of food in the socio economic development of any country cannot be over emphasized. The overall effect of food insecurity is not only inadequate food production but also imbalances in the nutritional status of the populace at large.

The dearth of animal products in the diet of an average Nigerian has been diminishing from year to year, mainly due to poverty, high cost of animal feeds, political and economic instability coupled with decreased interest in animal production while greater efforts are directed towards petroleum exploitation (Aderolu 2003).

The production and supply of meat and eggs to meet the people's dietary demand for animal protein is of great concern (Olubamiwa et al 2002). This shortage and high demand of cereals in Nigeria constitute a limiting factor to the economics of the production of poultry products (Adejumo 2004); it was also reported that feed quality and feeding costs have become critical parameters for successful animal production (Hossain et al 2003).

Pressure from consumers for cheaper animal products have necessitated the assessment of local feed ingredients as sole diets in replacement of conventional ingredients during the periods of scarcity and soaring costs 
(Oluokun 2001). In the coming years, poultry producers will definitely have to look beyond maize and other cereal grains because of their low availability; cost and inability to keep pace with ever-increasing poultry production (Chauynarong et al2009)

Cassava is a multipurpose plant that thrives well in the tropics, it is a very good energy source widely grown in Nigeria. It has a wide range of adaptability, resistance to drought and tolerance to poor soils (Tewe 1994). Most available literature on cassava utilization in poultry centered on either the use of its root or leaf meal and its root sieviate (Tewe and Egbunike 1992, Aderemi et al 2000, Aderemi et al 2006,). It is preferable to use the whole cassava plant to take advantage of the high protein content in the leaves, the bulk in tender stems and the high energy of the tuberous roots (Tewe 1991).

This study was embarked upon to contribute to the solution of inadequate animal protein consumption of Nigeria populace, which is primarily due to very high cost. This paper looked at the effects of inclusion of whole cassava meal as a replacement to maize in the diets of egg type chicken. The output aims at obtaining cassava rations that can be packaged for promotion to farmers in Nigeria and other tropical countries.

\section{Materials and methods}

\subsection{The Experimental Diets}

Cassava roots, leaves and tender stem were harvested from International Institute of Tropical Agriculture (IITA) Ibadan Nigeria. The unpeeled roots were washed chopped, dried until a constant weight was achieved before it was now ground with harmer mill machine. The leaves and tender stems were also harvested chopped, dried and ground separately. To standardize $20 \mathrm{~cm}$ of the top shoots without leaves of the plant were the part harvested as the tender stems. The ground root, leaves and tender stems were now mixed at ratio 3:6:1 to get the product which was tagged whole cassava meal (WCM)

Five diets were later compounded for this study diet I which had 50\% of maize served as the control, in diets II $-\mathrm{V}$ the test ingredient WCM was now incorporated to replace the maize portion at graded levels of 25, 50,75and $100 \%$. Other ingredients were added to make a complete feed as can be seen in table 2 . It was formulated such that the calculated gross energy varied from $1945-2525 \mathrm{kcal} / \mathrm{kg}$ and the crude protein content ranged from $19.76-20.76 \%$ which met the requirement of the experimental birds.

\subsection{Birds and their management}

The study was carried out at the Teaching and Research farm of Bowen University Iwo with the environmental temperature range of $15-28^{\circ} \mathrm{C}$ during the harmattan season and $20-36^{\circ} \mathrm{C}$ in the hot season. It receives an annual rainfall of $1400 \mathrm{~mm}$ which falls from April to October. Two hundred and fifty laying chicken of Yafa strain were purchased raised on commercial ration purchased from a reputable feed manufacturer in Nigeria. The feeding experiment commenced with one hundred and fifty 40 weeks old layers selected from the stock of laying birds. The layers were housed in battery cages and divided into fifteen groups of ten per set, three groups were randomly assigned to each set of dietary treatment, and the feed and water were provided ad libitum. All the birds were fed for a period of twelve weeks.

Standard routine management and vaccination were carried out which include draining of remaining water, washing of the watering trough and supply of fresh clean cool water. Removal of poultry dropping from the remaining feeds in the feeders and addition of fresh feed on daily basis (Aderemi et al 2006). Records of feed intake, weight gain, feed efficiency and egg production were determined weekly on all replicates.

\subsection{Egg Quality Analyses}

Percent hen day production was calculated as the percent of the ratio of the total number of eggs and the total number of days by number of hen i.e [total number of eggs/ (total number of days x number of hens)] x 100 . Weekly egg production was determined by collecting eggs laid per replicate every day and pooling together so as to count the total eggs collected for seven days. Parameters measured included the haugh unit, yolk weight, albumen weight, hen day production; for egg quality measurement five eggs per replicate were randomly selected from the eggs laid on the last day of every week. The weights were taken and the eggs were broken with the aid of a blunt edged knife so as not to rupture the albumen. The contents of each egg so broken were carefully transferred to a clean level glass plate. Albumen height was measured using a tripod micrometer, while the shell was peeled off its membrane and allowed to dry for a day under room condition and its thickness measured at the broad narrow and equatorial regions with a micrometer screw gauge. The egg length and width were measured with the use of vernier caliper. The shell surface area (SSA) was calculated according to the method of (Hughes 1984) and adopted by (Lewis and Perry 1987) as follows Egg weight ${ }^{0.667} \mathrm{x} 4.67$. The eggshell 
index was calculated as the ratio of the egg width to the egg length. The haugh unit was calculated using the formula

Where $\mathrm{Hu}=$ Haugh unit \%

$$
\mathrm{Hu}=100 \log \mathrm{H}+7.57-1.7 \mathrm{~W}^{0.37} \text { (Haugh 1937) }
$$

$\mathrm{H}=$ albumen height

$\mathrm{W}=$ egg weight $(\mathrm{g})$

The yolk color was subjectively scored by three research fellows using the Roche color fan and the average recorded per diet.

\section{Chemical analysis}

Samples of diets were analyzed for proximate composition and detergent fiber components using the procedures of AOAC (2000) and Goering and Van Soest (1970) respectively.

\section{Statistical analysis}

All data were subjected to analyses of variance while treatment means were separated by Duncan multiple range method using package of SAS (2001).

\section{Results and discussion}

Table 1 showed the proximate composition of the WCM and maize, the crude protein value obtained from WCM is $7.94 \%$ which is a little less than that of maize $9.0 \%$ it had $4.36 \%$ of crude fiber which is higher than $2.0 \%$ of maize.

Table 2 showed the gross composition of the experimental diets. The control and other experimental diets were formulated to meet the minimum nutrient requirement of laying hens.

\subsection{Performance characteristics of the layers}

The feed intake in table 3 revealed significant decrease $(\mathrm{P}<0.05)$ as the level of WCM was increasing. The final body weight of the experimental birds were highest in diets I and II implying WCM could actually replace maize at $25 \%$ without adverse effect on the weight gain of the layers. At this level of inclusion WCM was able to supply energy that was comparable to that of control diet and thus met the birds' requirement when fed ad libitum. The feed intake also had same statistical trend as the weight gain, while the feed: gain ratio which was calculated as the feed consumed per dozen egg laid revealed similarity statistically between layers fed diet I and II, while these were statistically $(\mathrm{P}<0.05)$ higher than III, IV and V. This implied that WCM could replace maize up to $25 \%$ in layers without adverse effect on egg production. The findings on feed intake which decreased as the level of WCM inclusion increased was a likelihood of poor utilization of WCM due to either high dietary fiber level or residual level of hydro cyanide in the diets. These had been implicated to affect pattern of protein utilization in animal this is in agreement with (Oluokun 2001). It was also reported that cyanide causes reduction in growth rate by inhibiting intra -thyroidal uptake of iodine, causing increase in secretion of thyroid stimulating hormone (TSH) and thereby causing a reduction in thyroxin level which is necessary for growth (Tewe 1994). This was similar to the findings of authors who also reported a decreasing daily feed intake as the level of cassava increased in the experimental diets of the layers (Eruvbertine 1995, Eruvbertine \& Oguntona 1997 and Matanmi et al 2005).

\subsection{Egg qualities parameters}

Table 4 revealed the egg characteristics parameter of the fed layers. Hen day production revealed there was similarity between layers on diet I and II. This is an indication that the inclusion of WCM in layer diets up to $25 \%$ adequately maintained body weight, which helps in sustaining efficiency of egg production. This was similar to our earlier findings which showed that feeding egg type chicken with supplemented cassava root sieviate CRS had no adverse effect on hen day production (Aderemi et al 2006). However the result showed that as the WCM inclusion increased beyond $25 \%$ the hen day production decreased, this perhaps could be likened to feed restriction and the outcome here agrees with the findings of (Degen et al 1988) who stated feed restriction negatively affected egg production of layers. This may be due to the increase in the amount of dietary fiber as the WCM increased in the diet, fiber had been reported to form complexes with other nutrients thereby preventing their breakdown and utilization thus egg production decreased. This is at variance with (Eruvbertine and Oguntona 1997) who reported high egg production values for hen fed unpeeled cassava diet for a four months laying period. From the percent hen day production it can be deduced that WCM could replace $25 \%$ of maize with a consequent reduction in the cost of the overall feed. 
The shell thickness and albumen was however not significantly affected $(\mathrm{P}>0.05)$ by the dietary treatment. The non significance of shell thickness implied all the dietary treatments were adequate in calcium which was similar to a finding that cassava based diet did not interfere with calcium metabolism in the laying hen (Lawal 1992). Shell thickness which is a function of the calcium and phosphorus levels in layers ration was not negatively affected as a result of the inclusion of WCM. Egg shell thickness is also an indication of the specific gravity (relative density of eggs) since both are positively correlated (Oluyemi and Robberts 1979). It could therefore be extrapolated that the inclusion of WCM has no depressing effects on the specific gravity of egg. Yolk colour was improved by the inclusion of WCM in the layers diet. It has been established that cassava leaf has high carotene content which enriches the yolk colour of the egg. Carotene had earlier been reported as vitamin A precursor. Yolk weight and haugh unit did not have a particular statistical trend by implication the inclusion of the WCM in layers diet might not have adverse effect on these parameters. Infact the haugh unit which is an indication of the egg quality for this study agree with standard values in most cited literature (Oluyemi and Robberts 1979). The absence of mortality among all the experimental birds showed that WCM may have been innocuously reduced of its cyanide, tannin and phytin antinutrient contents during processing this agree with previous findings of (Tewe 1991) and (Fasuyi 2005).

In the main the inclusion of $25 \% \mathrm{WCM}$ was found economical and productive as it was able to support body maintenance and egg production of the hen at a level which was comparable to those on control. Harnessing these by-product as poultry feed ingredient will also help to solve problem of pollution as dumping of these at processing site constitute nuisance to man.

\section{Acknowledgement}

The Author want to appreciate the management of International Institute of Tropical Agriculture (IITA) Ibadan for providing the cassava used for the study also Bowen University Iwo Osun State where the study was carried out.

\section{References}

Adejumo, D.O. (2004). Performance, Organ Development and Daematology of Rats Fed Sole Diets of Graded Levels of Cassava Flour and Soybean Flour (Soygari) as Substitutes for Energy and Protein Concentrates. Trop J Anim. Sci, 7 (1): 57 -63.

Aderemi, F.A. Lawal, T.E. Iyayi, E.A. (2006). Nutritional Value of Cassava Root Sieviate and Its Utilization by Layers. The Journal of Food Tech in Africa, 4(3), 216-220.

Aderemi, F.A. Tewe, O.O. and Ogundola, F.I. (2000). Metabolizable Energy of Supplemented and Unsupplemented Cassava Root Sieviate in Cassava Based Diet of Pullet Chicks. Trop.Anim.Prod. Invest., 3:107-115.

Aderolu, A.Z. (2003). Biodegradation of Fibrous Fed Ingredients and Their Utilization by Broilers and Layers. A Ph.D Thesis Submitted to the Department of Animal Science University of Ibadan, Nigeria.

AOAC. (2000). Official Methods of Analysis $16^{\text {th }}$ ed Assoc. Offic. Anal.Chem., Washington D.C.

Chauynarong, N. Elangovan, A.V. Iji, P.A. (2009). The Potential of Cassava Products in Diets for Poultry. World Poultry Science Association, 65: 23-35. http://dx.doi.org/10.1017/S0043933909000002

Degen, A. A. Kam, M. Rosentbrauch, S. (1988). Efficiency of Utilization of Energy for Egg Production in Feed Restricted Single Comb White Leghorn Hens. J. Agric Sci. Camb., 3:303-308.

Eruvbertine, D. (1995). Processing and Utilization of Cassava as Animal Feed for Non-Ruminant Animals. Paper Presented at the Workshop on Alternative Feed Stuffs for Livestock.Lagos.pg4-10

Eruvbertine, D. Oguntona, E.B. (1997). Unpeeled Cassava Root Meal in Diets for Laying Hens. Tropical Agric Trinidad, 44:299-302.

Fasuyi, A.O. (2005). Nutrient Composition and Processing Effects on Cassava Leaf (Manihot esculenta crantz) Antinutrients. Pakistan Journal of Nutrition, 4(1):37-42. http://dx.doi.org/10.3923/pjn.2005.37.42

Goering, H.K. Van Soest, P.J. (1970). Forage Fiber Analysis. Agriculture Handbook, No.379 ARS.USDA.

Haugh, R.U. (1937). The Haugh Unit for Measuring Egg Quality. U.S. Egg Poultry Magazine, 43:552.

Hossain, M.D. Ahammad, M.U. Howlider, M.A.R. (2003). Replacement of Fish Meal by Broiler Offal in Broiler Diet. International Journal of Poultry Science, 3:102-110.

Hughes, R.J. (1984). Estimate of Shell Surface Area from Measurement of Length,Breath and Weight of Hen eEggs. Poultry Science, 63:2271-2427. 
Lawal, O.O. (1992). Cassava Utilization in Laying Hens. B A Thesis Submitted to the Dept of Anim.Prod and Health University of Agriculture (UNAAB) Abeokuta.

Lewis, P.D. Perry, G.C. (1987). Interaction of Age, Interrupted Lighting and Genotype on Shell Weight and Density. British Poultry Science, 28:772.

Matanmi, O., Akinfala, E.O. Aderigbeş, A.O. Akinsuyi, M.A. (2005). Evaluation of the Nutritive Value of Whole Cassava Plant Meal (WCPM) as a Replacement for Maize in Cockerel Chicks Diets in the Humid Tropics. Ife Journal of Agriculture, 21:167-175.

Olubamiwa, O. Otun, A.R. Longe, O.G. (2002). Dietary Inclusion Rate of Cocoa Husk for Starter Cockerels. International Journal of Poultry Science, 1:133-135. http://dx.doi.org/10.3923/ijps.2002.133.135

Oluokun, J.A. (2001). Performance of Growing Rabbits Fed a Low Protein Diet Supplemented with Urea or Roasted Soybean Meal. Journal Animal Production Research, 17:89-99.

Oluyemi, J.A. Roberts, F.A. (1979). Poultry Production in Warm Wet Climate Macmillan Tropical Agriculture, Horticulture and Applied Ecology series, pg:13-15

SAS Institute. (2001). SAS/STAT Guide for Personal Computers, Version and Edition (Cary North Carolina SAS Institute.

Tewe, O.O. Egbunike, G.N. (1992). Utilization of Cassava in Non Ruminant Livestock Feed. Proceedings IITA/ILCA/University of Ibadan Workshop on the Potential Utilization of Cassava as Livestock Feed in Africa.Eds.S.K.Hahn,L Reynolds and G.N Egbunike pg:28-38.

Tewe, O.O. (1991). Detoxification of Cassava Products and Effects of Residual Toxins on Consuming Animals. In Proceedings FAO Expert Consultation Held in CIAT, Cacc Columbia Eds D. Machin and S.Myrold $21-25$ Jan pg 16.

Tewe, O.O. (1994). Indices of Cassava Safety for Livestock Feeding: Being Paper in International ACTA Horticulturae Workshop on Cassava Safety. IITA Ibadan pg: 241-248.

Table 1. Proximate composition of WCM and Maize

\begin{tabular}{|l|l|l|}
\hline Parameters & WCM $(\%)$ & Maize(\%) \\
\hline Dry matter & 90.56 & 88.00 \\
\hline Crude protein & 7.94 & 9.00 \\
\hline Crude fiber & 4.36 & 2.00 \\
\hline Ether extract & 3.33 & 4.00 \\
\hline Ash & 3.02 & 4.05 \\
\hline Nitrogen free extract & 71.91 & 69.95 \\
\hline
\end{tabular}

Table 2. Gross composition of the experimental diets

\begin{tabular}{|l|l|l|l|l|l|}
\hline & & & Diets & & \\
\hline Ingredients & I & II & III & IV & V \\
\hline Maize & 50 & 37.50 & 25.00 & 12.25 & - \\
\hline WCM & - & 12.50 & 25.00 & 37.50 & 50 \\
\hline Wheat bran & 18.40 & 18,40 & 18.40 & 18.40 & 18.40 \\
\hline Groundnut cake & 6.00 & 6.00 & 6.00 & 6.00 & 6.00 \\
\hline Soybean meal & 19.00 & 19.00 & 19.00 & 19.00 & 19.00 \\
\hline Fish meal & 3.00 & 3.00 & 3.00 & 3.00 & 3.00 \\
\hline Bone meal & 2.00 & 2.00 & 2.00 & 2.00 & 2.00 \\
\hline Oyster shell & 1.00 & 1.00 & 1.00 & 1.00 & 1.00 \\
\hline *Premix & .25 & .25 & .25 & .25 & .25 \\
\hline Salt & .25 & .25 & .25 & .25 & .25 \\
\hline Methionine & .10 & .10 & .10 & .10 & .10 \\
\hline Calculated analyses & & & & & \\
\hline CP \% & 20.76 & 20.12 & 19.90 & 19.87 & 19.76 \\
\hline ME kcal/Kg & 2525 & 2516 & 2218 & 2013 & 1945 \\
\hline
\end{tabular}

*To provide the following per kg diet, vitamin A 10,000in, vitamin D3 1500iu, Vitamin E3iu, Vitamin K 2mg, riboflavin 3mg, Panthothenic acid 6mg, niacin $15 \mathrm{mg}$, chlorine $5 \mathrm{mg}$, vitamin B12 $0.08 \mathrm{mg}$, folic acid $4 \mathrm{mg}$, Mn $8 \mathrm{mg}, \mathrm{Zn} 0.5 \mathrm{mg}$, iodine $1.0 \mathrm{mg}$, Co $1.2 \mathrm{mg}$ and Fe $20 \mathrm{mg}$. 
Table 3. Performance characteristics of the layers fed

\begin{tabular}{|l|l|l|l|l|l|l|}
\hline & & & Diets & & & \\
\hline Parameters & I & II & III & IV & V & SEM \\
\hline Final body weight kg & $1.78^{\mathrm{a}}$ & $1.75^{\mathrm{a}}$ & $1.69^{\mathrm{b}}$ & $1.57^{\mathrm{b}}$ & $1.21^{\mathrm{c}}$ & 0.56 \\
\hline Weight gain g/day & $18.20^{\mathrm{a}}$ & $18.05^{\mathrm{a}}$ & $14.86^{\mathrm{b}}$ & $12.69^{\mathrm{b}}$ & $9.06^{\mathrm{c}}$ & 0.34 \\
\hline Feed intake g & $99.52^{\mathrm{a}}$ & $90.70^{\mathrm{a}}$ & $85.33^{\mathrm{b}}$ & $77.32^{\mathrm{b}}$ & $55.45^{\mathrm{c}}$ & 0.01 \\
\hline Feed /gain ratio & $65.46^{\mathrm{a}}$ & $64.31^{\mathrm{a}}$ & $60.59^{\mathrm{b}}$ & $56.67^{\mathrm{c}}$ & $45.98^{\mathrm{d}}$ & 4.45 \\
\hline Feed cost $/ \mathrm{kg}$ feed & $48.00^{\mathrm{a}}$ & $40.50^{\mathrm{b}}$ & $38.00^{\mathrm{b}}$ & $35.00^{\mathrm{b}}$ & $25.00^{\mathrm{c}}$ & 0.96 \\
\hline
\end{tabular}

abc Means with the same superscript along a row are not significantly different $(\mathrm{P}>0.05)$

Table 4. Egg quality parameters

\begin{tabular}{|l|l|l|l|l|l|l|}
\hline & & & Diets & & & \\
\hline Parameters & I & II & III & IV & V & SEM \\
\hline Shell thickness (mm) & 0.33 & 0.31 & 0.35 & 0.36 & 0.36 & 0.44 \\
\hline Yolk weight $(\mathrm{g})$ & 25.93 & 24.27 & 24.45 & 25.43 & 24.73 & 0.53 \\
\hline Albumen weight(g) & 61.42 & 62.76 & 62.05 & 63.35 & 60.23 & 1.13 \\
\hline Yolk colour & $1.70^{\mathrm{a}}$ & $1.68^{\mathrm{a}}$ & $1.63^{\mathrm{b}}$ & $1.66^{\mathrm{b}}$ & $1.64^{\mathrm{b}}$ & 0.35 \\
\hline Haugh unit \% & $72.93^{\mathrm{c}}$ & $80.04^{\mathrm{a}}$ & $77.77^{\mathrm{b}}$ & $72.22^{\mathrm{c}}$ & $73.44^{\mathrm{c}}$ & 0.16 \\
\hline Hen day production\% & $60.82^{\mathrm{a}}$ & $60.21^{\mathrm{a}}$ & $56.34^{\mathrm{b}}$ & $54.60^{\mathrm{b}}$ & $48.29^{\mathrm{c}}$ & 0.39 \\
\hline
\end{tabular}

abc Means with the same superscript along a row are not significantly different $(\mathrm{P}>0.05)$ 